\title{
С.О.Буцикіна,
}

кандидат філософських наук, асистент кафедри етики, естетики та культурології філософського факультету КНУ імені Тараса Шевченка

\section{ТРАНСФОРМАЦІЯ КАТЕГОРІЇ «ПОТВОРНЕ» В МЕЖАХ ПОСТНЕКЛАСИЧНОГО ЕСТЕТИЧНОГО ДИСКУРСУ}

Спостерігаючи за розвитком сучасного українського мистецького простору, можна виокремити загрозливу тенденцію неспівимірності його аналізу на рівні естетичної теорії та мистецької практики (в межах останньої - неспівимирність позицій автора, критика та реципієнта). Подібний стан спричинений низьким рівнем знання сучасних тенденцій розвитку світового мистецтва, а також його історичного підгрунтя. Тому вважаємо за необхідне простежити одну з магістральних ліній - розгортання теоретичного дискурсу співвідношення категорій прекрасного та потворного, в межах якого відзначається змістовне та ціннісне домінування прекрасного, що з часом втрачає свій статус, власне, як і категоріальність саму по собі. Це відбувається за рахунок віднайдення альтернативних понять та концептів в естетичній теорії, зокрема, поняття безформного, визначення якого запропонував французький філософ Жорж Батай [5].

Характерною рисою постнекласичного етапу трансформації естетичного досвіду постає увага до безформного та мерзенного (множинного, рухливого, слизького як більш конкретних форм). Ці терміни відповідають змісту трансгресивного досвіду як здійснення виходу на новий рівень чуттєвого, що втрачає власні форми. Звернення до безформного в контексті чуттєвого відповідає зверненню до неможливого в межах власного досвіду. Принциповий вихід «поза» характеризується специфічним чуттєвим станом суб'єкта досвіду, що супроводжується руйнуванням чітких, ієрархізованих меж між суб'єктом та об'єктом сприйняття. Подібний стан не заперечує власні естетичні засади, проте розширює простір естетичного досвіду, руйнуючи його межі.

Естетичні дослідження категорії «потворне» мають глибинну 
історію, починаючи від К.Розенкранца, продовжуючи дослідженнями Б.Бозанкета та Т. Адорно і завершуючи сучасним переосмисленням традиційного статусу даної категорії в працях Дж.Белла, В. Бахметьєваса, М.Куплен, вітчизняної дослідниці М.Шкепи та ін.

Питанню місця концепту «безформного» в естетичній теорії та мистецькій практиці XX та XIX ст. було присвячено дві антології: «Безформне: керівництво користувача» [8] та «Безформне: шляхи до форми та від неї» [8] [10]. Формат антології невипадковий, адже для дослідників даного поняття $є$ принципово важливим залишити плюралістичність поглядів на його смисли, модифікації та шляхи реалізації в сучасному мистецтві та культурі, на відміну від монологічності й тотальності категоріального аналізу некласичної естетики.

«Мерзенність», або «ницість», для світового естетичного дискурсу відкрила Ю.Крістєва, відобразивши у даному понятті синтез психоаналітичної теорії Ж. Лакана та концепції «низького матеріалізму» Ж.Батая. В подальшому це поняття розвивали Р.Краусс, Д.К.Ковіно та ін.

Метою нашого дослідження $\epsilon$ історичний аналіз трансформації естетичної категорії потворного (вперше проаналізованої К.Розенкранцем) в поняття безформного (Ж. Батай) та мерзенного (Ю.Крістєва).

На варіативність естетичного за рахунок потворного, надаючи йому статус категорії, вперше звернув увагу К.Розенкранц, німецький філософ, учень та адепт Г.В.Ф.Гегеля, у праці «Естетика потворного» (1853). Розенкранц вперше аналізує потворне в межах некласичної, експліцитної естетики, використовуючи діалектичний метод, відповідно до якого ця категорія розглядається в якості контрасту для повного вираження прекрасного: як у природі, так і в мистецтві. Розенкранц визначає потворне як «негативне опосередкування поняття прекрасного в-собі та комічного» $[3,63]$. Принципово важливою характеристикою подібного розмежування постає поняття форми, що уточнюється через наявність чіткої межі об'єкта як необхідну умову його як цілого (нім. Gestalt): «...Поняття абстрактної детермінації форми виражає логіку прекрасного, оскільки повністю абстрагується від змісту і володіє тією самою формою необхідності для будь-якого типу краси, безвідносно до матеріалу, в якому вона реалізується, та безвідносно до способу духовного втілення» [3, 63]. Розенкранц виокремлюе три модальності вияву потворного: аморфність, асиметрію та дисгармонію. Аморфність як основна модифікація 
потворного, вираженого через відсутність форми, у своїй абсолютності постає неможливою, з точки зору естетичного аналізу, і не може бути оцінена ні як прекрасна, ні як потворна. Отже, Розенкранц визнає необхідність відносної аморфності як засобу вияву прекрасного в певному предметі, зосереджуючи увагу на інструментальному характері даної модифікації потворного. Таким чином, він вибудовує «класичне» розуміння потворного як необхідної тіні (антитези) прекрасного в природі, для подальшого зняття («трансгресії», за Ж.Батаєм), що реалізовується в якості прекрасного в мистецтві (відповідно до постулатів філософії мистецтва Гегеля).

Якісну трансформацію категорії потворного можна спостерігати вже у першій половині XX ст. Французький журнал «Документи» (1929-1930) формально спеціалізувався на мистецтвознавстві та етнографії, проте змістовно був присвячений розробці трансгресивного досвіду авторів та читачів в межах зазначених галузей знання. Журнал мав подвійну спрямованість: звернення до високого, відірваного від повсякденності, та, водночас, детальний аналіз найбільш низького, огидного, вульгарного, що існує в межах людської культури. Ж. Батай та його колеги (насамперед, М. Лейріс та М.Гріоль) зосереджували увагу на дослідженні елементів антиестетичного, які, на їх думку, мали сакральне значення, пов'язане з певним трансцендентним началом, та були витіснені за межі свідомості людини ХХ ст. Найбільш яскравим прикладом є статті «Плювок» М.Гріоля та М.Лейpica, а також «Безформне», «Пил» Ж.Батая. Безформне є проявом, різновидом антиестетичного. «Плювок», який служив найбільш яскравим прикладом безформного, став викликом поняттю «прекрасне» в будь-якому його вигляді, в тому числі й тому провокативному, «конвульсивному» прекрасному, що обстоювали у своїх теоретичних дослідженнях та виражали в мистецьких творах сюрреалісти.

Безформне Ж. Батая за значенням є виходом за межі споглядальної цінності об'єкта естетичного досвіду, переходом від сфери чуттєвого до сфери містичного, священного, в їх негативному модусі - низького та безформного. Безформне не заперечує естезис як простір чуттєвого сприйняття, проте звертається до його меж і конституює їх розмитість. Власне, саме аналіз безформного у Ж.Батая є початком розгортання концепції трансгресивного. Трансгресивний досвід як антиестетичний не $\epsilon$ запереченням досвіду естетичного. Проте він постає його кінцевою негативною формою, що сприяє розширенню та розвитку простору естетичного досвіду в межах як теоретичної 
думки, так і художньої практики XX ст.

В подальшому ідея безформного набула концептуалізації у вигляді елементу концепції «низького матеріалізму» (фр. «bas matŭrialisme»). На думку Батая, прокляте, вигнане на периферію, плотське, «тваринне» життя було піддане моральному осуду та асоційоване зі злом в межах християнського світогляду. В результаті ці поняття опинилися за межами дискурсу західної релігійної філософії. Безпосередньо пов'язана 3 органічним життям, нижча матерія (тобто все, що можна віднести до потворного та низького) також відкидається традиційною естетикою прекрасного. Починаючи 3 античної протоестетики, категорії потворного та низького стосувалися лише всього, чому можна було приписати дисгармонійність та диспропорційність. Як зазначає О.Д. Чінчія, «потворне було зведене до його розуміння як певного рівня прекрасного, якомога найнижчого рівня» [6, 327]. Лише К.Розенкранц виводить аналіз потворного як «категорії» на новий рівень, водночас доводячи його традиційне розуміння до довершеного стану. Як зазначає Г.Паррет, «унікальна «Естетика потворного» є видатною 3 двох причин. 3 одного боку, вона вписується у винятково систематичну та сильну теорію, в якій потворність стосується гри формального та безформного, а з іншого, - потворне введене всупереч унікально деталізованій феноменології та (частково) перетинається з суміжними категоріями на кшталт вульгарного, низького, відразливого, карикатурного, примарного тощо. Розенкранц не вагається ні на мить: звичайно, естетичний досвід потворного існує» $[9,9]$.

Так, Паррет дає старт подальшим автономним досліджень потворного як естетичної категорії. В.Бахметьєвас проводить чітку хронологічну лінію даних розвідок: «Розенкранц, Бозанкет та Адорно пропонують три схожі, проте оригінальні інтерпретації присутності потворного в мистецтві. Інтерпретація потворного як тіні прекрасного у Розенкранца, концепція «складної краси» у Бозанкета та розуміння потворного як культової присутності в мистецтві у Адорно є глибоким та оригінальним внеском в естетику» $[4,34]$.

Проте, саме Ж.Батай докорінно змінює ситуацію, руйнуючи традиційну дихотомічну категоріальність введенням поняття «безформне». Онтологія французького мислителя постає 3 того факту, що суперечність між прекрасним і потворним, високим і низьким, духом і природою - нерозв'язне: перше існує остільки, оскільки існує друге. Проте, на відміну від попередніх досліджень взаємо- 
зв'язку протилежних естетичних понять та категорій, увага принципово зосереджена на потворному та низькому.

«Низький матеріалізм», за Ж.Батаєм, - це визнання чужорідного для суб'єкта активного начала, пов'язаного зі злом, смертю і руйнуванням, із тілесністю і сексуальністю. Зазначимо, у французькій мові «низький», «базисний», «основний» (фр. «bas») - це споріднені слова. Це дає можливість Батаю грати 3 їх значенням. Мислитель звертається до ідей 3. Фрейда: низька матерія, як розуміється як соціальний і психологічний феномен, подібна до фрейдівського «несвідомого», що витісняється культурою. Так, Ж.Батай проголошує відмову від попереднього ієрархізованого чуттєвого сприйняття та естетичної оцінки. Безформне постає поза дуальностю прекрасного та потворного, в межах пошуку нових можливостей чуттєвого пізнання, що відповідатимуть потребам нового часу постмодерної доби. Дослідники творчості сюрреалістів крізь призму статей Ж.Батая, Д.Ейдс та С.Бейкер в якості ілюстрації безформного використовують творчість Ж. Арпа. Його абстрактні об'єкти надають можливість досвіду здійснювати безконечний пошук означуваного як сталого образу, на який може опертися реципієнт: обличчя нагадує тварину, тварина нагадує квітку тощо.

У другій половині XX - на початку XXI ст. концепт безформного продовжує розвиватися та набувати нових смислів у працях сучасних філософів, а також - проявів у творчості сучасних художників. Зокрема, Ю.Крістєва в працях «Революція поетичної мови» (1974) та «Сили жаху: Есе про ницість» (1982) запроваджує модифікацію безформного - поняття «мерзенне» (фр. abject) та похідний від нього іменник «ницість» (фp. abjection). Як зазначає Д.Феллуга, аналізуючи праці Крістєвої, «Досвід мерзенного в літературі несе з собою певне задоволення, але таке, що досить сильно відрізняється від динаміки бажання. Крістєва пов'язує цей естетичний досвід, скоріше, з поетичним катарсисом...» [7]. Дана модифікація дає можливість запровадити ще більшу варіативність естетичного проблемного поля та засобів вираження: починаючи від найдоступнішого образу слизу та продовжуючи в напрямі феміністичного дискурсу. Останній, як зазначає Р.Краусс, яскраво представлений у творчості С.Шерман - авторки серії автопортретів у впізнаваних, але дизгармонійних образах, що вражають відсутністю єдності та цілісності в них. Ці твори проблематизують безформність жіночого тіла в контексті традиційної та масової 
культур. Шерман розгортає «горизонтальний дискурс», який позбавлений ієрархії високого та низького (піднесеного та низького - в естетичній теоріï) та присутній топографічно на рівні «нижче низького» (англ. lower than low). Горизонтальний дискурс прирівнюється до фемінного, на противагу вертикальному - фалічному. Гіпертрофованим вираженням даної ідеї виявляється художня рефлексія на стан захворювання булімією - діагнозу, що відповідає нездатності здобути досвід відчуття власної форми, меж власної тілесності. Саме поєднання «abject art» та феміністичного мистецтва прокладає подальший шлях перетворення потворного у формі звернення до мерзенного як специфіки саме жіночого тіла, що позбавляє розірваності суб'єкт-об'єктних відносин: «Мерзенне, що розуміється як нерозрізнювальна матеріальна підкладка - на кшталт жіночного піднесеного, хоча воно й складається із безконечної невимовності тілесної відрази: крові, екскрементів, слизистих оболонок - врештірешт відлитих, в межах теоретизації мерзенного мистецтва, у множинних формах поранення. Бо, незалежно від того, чи піднімається тема жіночого в конкретній праці, саме властивість бути пораненою, принесеною в жертву, травмованою, маргіналізованою залучається у цій сфері» [8, 238].

В даному контексті повернімося до концепції Ж.Батая та розглянемо пов'язаність його поняття безформного та прояву в феномені сміху образу жінки в його літературних творах. «Ця безформність, що виражає безмір порожнього бажання, - на думку М.Свстропова, стає непристойною, волає до смерті, до «ножу м'ясника». Таким же викликом виявляється і жіночий сміх (наприклад, сміх Епоніни в «Аббаті С.») - він сповіщає про відсутність Бога, він «атеологічний» - без жодного наміру. Разом $з$ тим, те «сакральне», що існує в «Мадам Едварді», пише Батай, перебуває наче «по той бік будьякого сміху» - i, насамперед, того непристойного, захисного сміху, що є реакцією на провокацію «чужорідного»» $[2,118]$.

«Жіноче» для Батая належить до «проклятої частини»: жінка виступає об'єктом жертовного витрачання, «непродуктивного споживання» $\mathrm{i}$, таким чином, набуває «сакралізованості». Витрата без всякого смислу і $є$ «суверенність». Зрештою, «жіноче» виявляється стихією тео-графії, гетерологічного уявлення Бога. Сценічним майданчиком цього подання у Батая стає, насамперед, прозаїчний цикл з характерною назвою «Divinus Deus» («Божественний Бог»), в якому увага автора зосереджується на образах «блудниць», кожна 
3 яких неодмінно проголошує відсутність Бога.

Винятковий варіант жіночого образу - образ матері. Суперечливість і трансгресивність естетичного досвіду автор передає за допомогою образу плоті. Ця плоть - безформне і байдуже материнське тіло, яке досить часто асоціюється з образами землі, розкладання, могили. Проте водночас матір є об'єктом трансгресивного досвіду: Батай часто описує сцену смерті матері героя, спостерігаючи яку герой відчуває збудження. Ця сцена є вигаданою, але одночасно може бути й алюзією до реальних подій. Батай спеціально не підтверджує до кінця жоден із варіантів: «коливання» на межі - це його мета як автора.

Втілення концепцій безформного Батая, а також мерзенного Крістєвої та Краусс можна побачити і в сучасному українському мистецтві на прикладі творчості художниці В.Ралко: «...Відразливе членування тіла, зображення якого має конкретні конотації ідентичності, вторгнення в неї і порушення іiі символічного порядку. Ба більше, гіпертрофовані жіночі тіла, на яких величезними кривавими ранами зяють вагіни - це і $є$ abject - досвід становлення/руйнування ідентичності через розрив із матір'ю або буквально, вихід із неї» [1]. Ралко, на відміну від Шерман та деяких митців-постмодерністів, поступально звертається до традиційних видів зображувального мистецтва - насамперед, до живопису, іноді до графіки та скульптури. Даний феномен на символічному рівні відображає сучасний стан втілення естетичного дискурсу у вітчизняному мистецтві: втілення радикальних для українського суспільства ідей через традиційний інструментарій.

Таким чином, історія трансформації категорії «потворне»у поняття «безформне» та «мерзенне» (або «ницість») постає відображенням динаміки розвитку естетичної теорії, що покликана описувати або навіть перетворювати західноєвропейську й українську художні традиції. Сьогодні ця трансформація продовжується у пошуках нових шляхів втілення для відповіді на запити нових соціально-історичних вимог. Естетичний аналіз трансформацій естетичного дискурсу сьогодення необхідно здійснювати крізь призму історичного контексту: за даної умови матимемо нагоду віднайти не лише негацію попереднього досвіду, а й вибудовування якісно нового у майбутньому. 


\section{ЛІТЕРАТУРА}

1. Баздырева Ася. Обратно в мать // Режим доступу: http://syg.ma/@asiabazdyrieva/obratno-v-mat [Електронне джерело]

2. Евстропов М.Н. Опыты приближения к «иному» в философском творчестве Жоржа Батая, Эмануэля Левинаса и Мориса Бланшо: дис. ... канд. филос. наук. - Томск, 2008. - $326 \mathrm{c}$.

3. Шкепу М.А. Эстетика безобразного Карла Розенкранца. - К., 2010. - 448 с.

4. Victoras Bachmetjevas. The Ugly in Art // hmogus ir hodis, 2007. - 04, Vol. 9. - C.29-34.

5. Georges Bataille, ed. «Critical Dictionary», in Encyclopaedia Acephalica: Comprising the Critical Dictionary and Related Texts, ed. Alastair Brotchie (London: Atlas Press, 1995)

6. Chinchilla, Oscar Delgado. Towards the Better Understanding of the Ugly in Literature // Revista de Lenguas Modernas, 2012, N.17, P.323-338.

7. Felluga, Dino. «Modules on Kristeva: On the Abject». Introductory Guide to Critical Theory // Режим доступу:

https://www.cla.purdue.edu/english/theory/psychoanalysis/kristevaabject.ht $\mathrm{ml}$ [Електронне джерело]

8. Krauss Rosalinde. The Destiny of the Informe // Formless: A User's Guide / Yves-Alan Bois and Rosalind Krauss (eds.) / New York, 1997. - 304 c. C. 235-252.

9. Parret Herman. On the beautiful and the Ugly // Wassard Elea Rivista. III, no 1; maggio 10, 2016. -52 c. - C.3-14.

Буцикіна Є.О. Трансформація категорії «потворне» в межах постнекласичного естетичного дискурсу.

В статті здійснюється спроба історичного та концептуального аналізу трансформації естетичної категорії потворного в поняття безформного та мерзенного, яка відображає загальне перетворення естетичного дискурсу та його перехід у постнекласичну добу. Поняття безформного розглядається в контексті концепції низького матеріалізму Ж.Батая. Поняття мерзенного (та ницості) досліджується крізь призму ідеї Ю.Крістєвої та Р.Краусс на прикладі творчості С.Шерман та В.Ралко. Лінія трансформації класичної естетичної категорії надає можливість вибудовування нового етапу розвитку вітчизняної естетичної думки на основі синтезу «мерзенного» та феміністичного мистецтва.

Ключові слова: Батай, безформне, Крістєва, мерзенне, ницість, потворне, Розенкранц. 
Буияыкина Е.А. Трансформация категории «безобразное» в рамках постнеклассического эстетического дискурса.

В статье осуществляется попытка исторического и концептуального анализа трансформации эстетической категории безобразного в понятие бесформенного и отвратительного, которая отражает общее преобразование эстетического дискурса и его переход в постнеклассический период. Понятие бесформенного рассматривается в контексте концепции «низкого материализма» Ж.Батая. Понятие отвратительного (и подлого) исследуется сквозь призму идеи Ю.Кристевой и Р.Краусс, на примере творчества С.Шерман и В.Ралко. Линия трансформации классической эстетической категории позволяет выстраивать новый этап развития отечественной эстетической мысли на почве синтеза «отвратительного» и феминистического искусств.

Ключевые слова: Батай, безобразное, бесформенное, Кристева, отвратительное, отвращение, Розенкранц.

Butsykina $Y$. Category of ugliness transformation within the aesthetic post-non-classical discourse.

The article attempts to analyze the historical and conceptual transformation of aesthetic category of ugliness, first analyzed by Karl Rosenkranz, into the concepts of formless and abject, which reflects the overall aesthetic discourse transformation and its transition to post-non-classical stage. Rosenkranz distinguishes three modalities of ugliness: amorphous, asymmetry and disharmony. Thus he builds a «classical» understanding of ugliness as desired shade of beauty in nature, to further sublation, realized as fine art. The concept of formless considered in the context of the «bas matŭrialisme» concept by Georges Bataille, as it arises out of duality of beauty and ugliness, ranging search for new opportunities and limits of sensory perception that meet the needs of postmodern era. The concept of abject (and abjection) studied in the light of the ideas of J. Kristeva and R. Krauss, on the base of S. Sherman and V. Ralko oeuvres. The concept of formless represented in its manifestation in the phenomenon of laughter within transgressive issues by contacting the image of women in literary works by Bataille. The analysis of classical aesthetic category transformation line allows to build a new stage of the national aesthetic thought development on the basis of «abject art» and feminist art synthesis.

Key words: abject, abjection, Bataille, formless, Kristeva, Rosenkranz, ugly. 